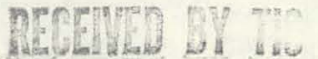

\section{HIGH-FREQUENCY FURNACE}

Technical Progress Report

DOE/CS/15077--T7

DE84 000425

Eighth Quarterly Report

Period ending September 30, 1983

Grant No. DE-FG01-81CS 15077

Submitted to the

U. S. Department of Energy

Office of Conservation and Renewable Energy

Inventions Support Division

by

Allen D. Zumbrunnen

419 Sherman Ave.

Salt Lake City, Utah 84115

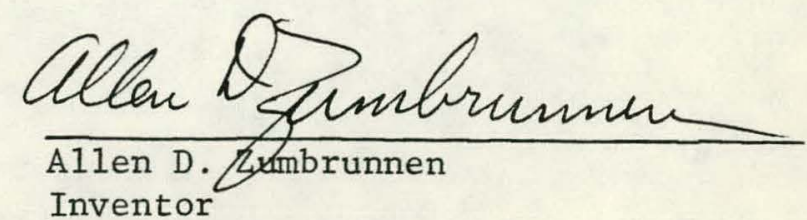

\section{DISCLAIMER}

This report was prepared as an account of work sponsored by an agency of the United States Government. Neither the United States Government nor any agency thereof, nor any of their employees, makes any warranty, express or implied, or assumes any legal liability or responsibility for the accuracy, completeness, or usefulness of any information, apparatus, product, or process disclosed, or represents that its use would not infringe privately owned rights. Reference herein to any specific commercial product, process, or service by trade name, trademark, manufacturer, or otherwise does not necessarily constitute or imply its endorsement, recommendation, or favoring by the United States Government or any agency thereof. The views and opinions of authors expressed herein do not necessarily state or reflect those of the United Statis Government or any agency thereof. 


\section{DISCLAIMER}

This report was prepared as an account of work sponsored by an agency of the United States Government. Neither the United States Government nor any agency Thereof, nor any of their employees, makes any warranty, express or implied, or assumes any legal liability or responsibility for the accuracy, completeness, or usefulness of any information, apparatus, product, or process disclosed, or represents that its use would not infringe privately owned rights. Reference herein to any specific commercial product, process, or service by trade name, trademark, manufacturer, or otherwise does not necessarily constitute or imply its endorsement, recommendation, or favoring by the United States Government or any agency thereof. The views and opinions of authors expressed herein do not necessarily state or reflect those of the United States Government or any agency thereof. 


\section{DISCLAIMER}

Portions of this document may be illegible in electronic image products. Images are produced from the best available original document. 
INTRODUCTION

An important phase of silicon solar cell production via ingot technology is the conversion of polycrystalline silicon to the single-crystal, ingot form that is required for wafering. In the current art such ingots are produced either by pulling from the melt or by various crucible growth techniques. A characteristic of all of these methods, which use bulk melting, is that a refractory crucible is required to hold the molten charge. This imposes the disadvantages that the silicon is always contaminated to some degree by dissolution of the refractory into the melt, which can reduce solar cell efficiency, and the crucibles themselves represent a significant cost factor. Clearly, elimination of the need for a refractory crucible in the melt growth of single-crystal silicon would be an important process improvement.

Work to be conducted under the present Grant Award is to investigate a radical, new heating technique which holds potential for achieving crucibleless melting. Ingots would be pulled from the melt as per conventional practice. The heating method to be employed is described in U. S. Patent 4,133,969. Briefly, a high frequency current $(10 \mathrm{KHz})$ is caused to flow on the surface of a mass of metal as a result of skin effect and proximity effect. By controlling the power input and heat losses from the billet it is anticipated that it will be possible to form and maintain in its top surface a molten pool which will be contained in a solid, outer layer or "sku11" of metal. The basic objectives of the project are to prove the general feasibility of this melting technique. This is to be accomplished by building and operating a small, experimental furnace. To simplify the project as much as possible and to minimize research costs, cast iron will be used in place of silicon for melt experiments. 
FURNACE CONSTRUCTION PROGRESS

The construction phase of the project continues to run somewhat behind schedule. This slippage is due mainly to the fact that the design and fabrication of a number of furnace components has taken longer than expected. Rather than rush this work it was decided to take whatever time was necessary to insure the best possible performance of the apparatus when it is completed.

Work during the past quarter has been concerned with the design and construction of various mechanical parts in the heat zone of the furnace and the fabrication of some busbar segments that will be located between the power supply and the furnace containment vessel.

\section{Heat zone}

The major component in this region of the furnace is the ductile iron casting which will become the "sku11" and molten pool when heating power is applied. Peripheral to this are the proximity conductor, which will be located near the top surface of the casting, and the skul1 support structure.

As described in Quarterly Report Number Six, the sku11 is housed within a number of sheet metal fins which serve the dual purpose of providing mechanical support and also acting as heat transfer surfaces (Fig. 1). These are non-rigidly mounted so that thermal expansion of the casting is accommodated in all directions. Electrical contact is made through four nickel alloy pins that are threaded into each end of the work-piece (Fig. 2). Because of the large magnetic stirring effect that is expected in the melt, a flow guard has been mounted on the top surface of the casting and generally outlines the area where melting is to occur.

The proximity conductor (PC) will be located just above the top surface of the casting (typically about $1 / 8^{\prime \prime}$ spacing) and will be mounted on sliding contacts which will allow its height to be adjusted during operation. 
The PC sliding joints must be made of copper and it was originally intended that welded construction would be utilized. However, because of the difficulty in obtaining sound welded joints in this material it was later decided to use silver brazing as an alternate technique, and one assembly of this type was made. This too proved to be only a marginally acceptable procedure, and other construction and design modifications are currently being examined.

\section{Busbar components}

The skull and melt are part of a resonant, electrical circuit which also includes a number of capacitors and a variable inductance. Tuning of the circuit is accomplished by manually changing taps on the capacitors and adjusting the inductance. All of these components are tied together by appropriate, copper busbar and various other linkages. Installation of this equipment is current1y underway.

\section{Remaining work}

1. Install work station capacitor bank and associated busbars .

2. Construct and install instrument panel for coolant flow rate and temperature monitoring.

3. Construct and instal1 instrument panel for monitoring electrical power input to the furnace.

4. Fabricate and install proximity conductor and sliding joint assembly.

5. Instal1 argon purging system.

6. Complete installation of remaining coolant lines and hook-up of instrumentation wiring. 


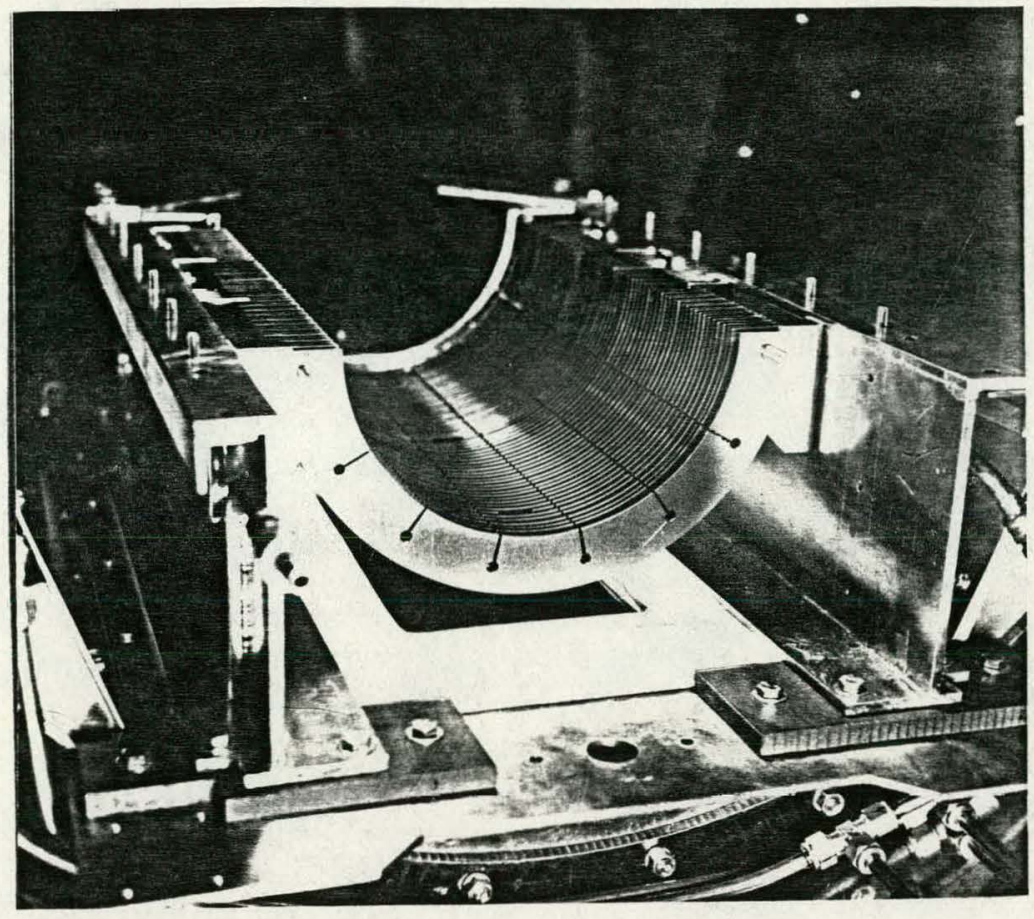

Fig. 1. Skull support

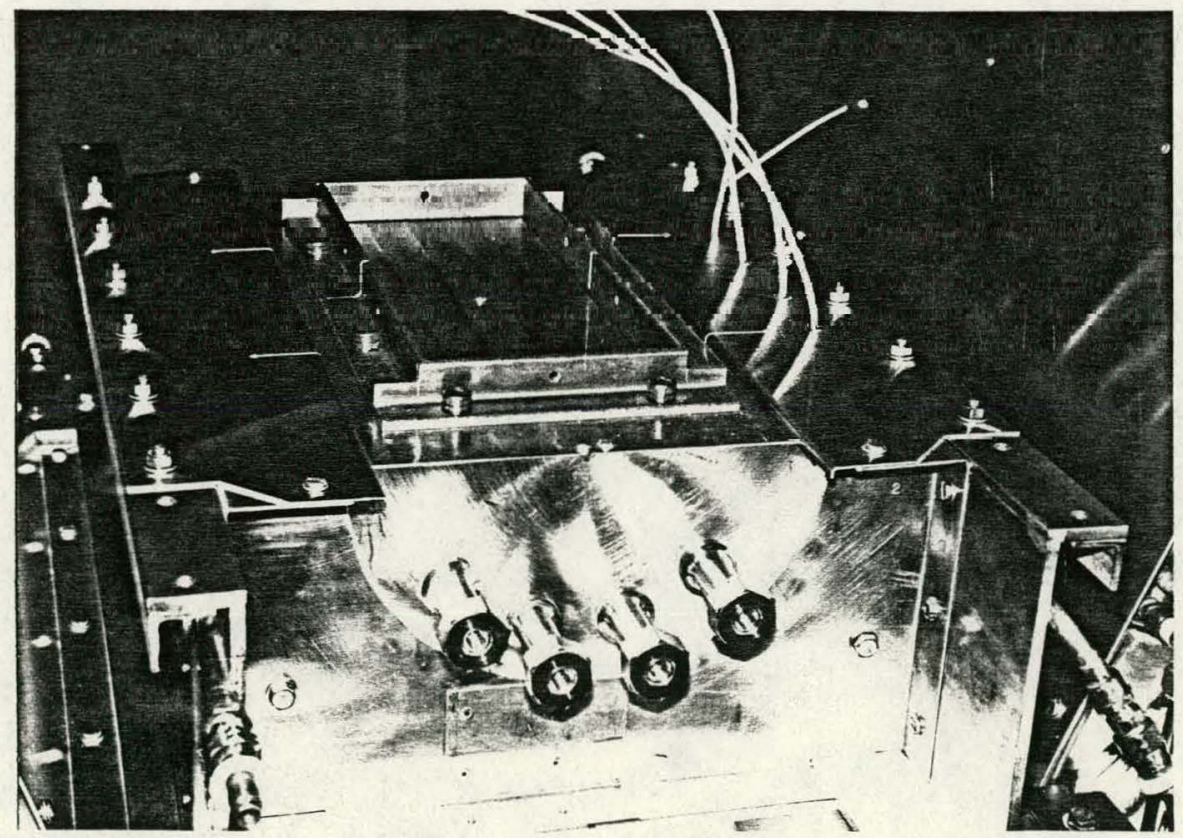

Fig. 2. Installed casting 


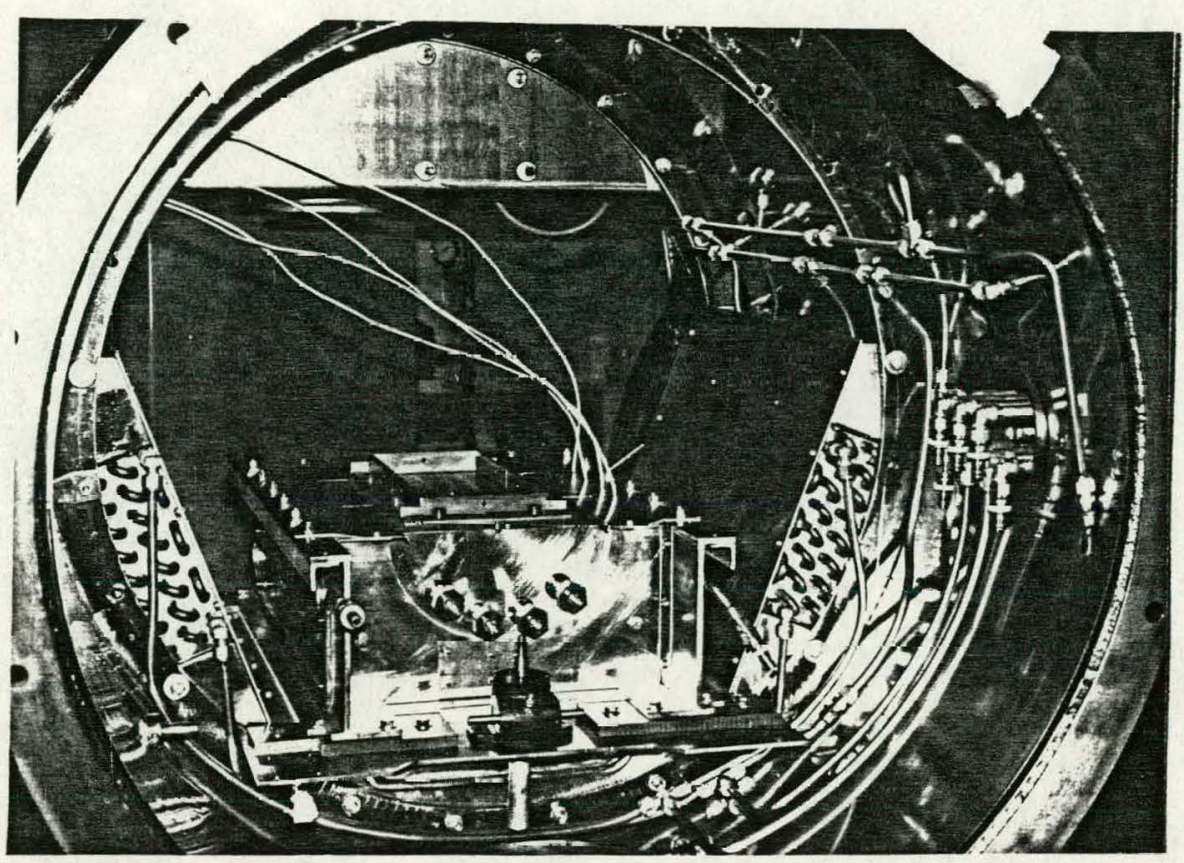

Fig. 3. Interior view of furnace

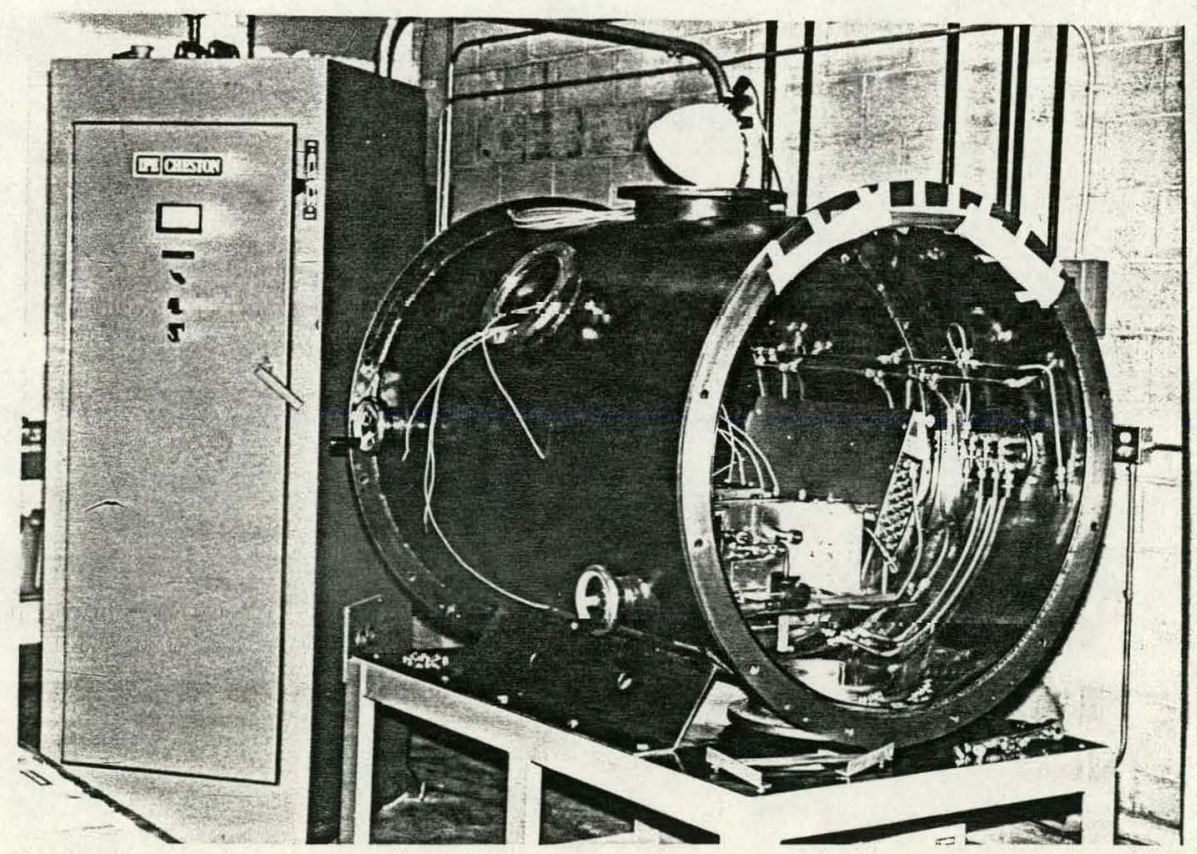

Fig. 4. Power supply and containment vesse1 